\title{
Differential Influence of Nerve Growth Factor on Neuropeptide Expression in vivo: A Novel Role in Peptide Suppression in Adult Sensory Neurons
}

\author{
V. M. K. Verge, ${ }^{1}$ P. M. Richardson, ${ }^{2}$ Z. Wiesenfeld-Hallin, ${ }^{3}$ and T. Hökfelt ${ }^{4}$ \\ 'Department of Anatomy, University of Saskatchewan, Saskatoon S7N OW0, Canada, ${ }^{2}$ Division of Neurosurgery, \\ Montreal General Hospital and McGill University, Montreal H3G 1A4, Canada, ${ }^{3}$ Department of Clinical \\ Neurophysiology, Karolinska Institute, Huddinge, Sweden, and ${ }^{4}$ Department of Neuroscience, Karolinska Institute, \\ Stockholm, Sweden
}

In this study the actions of NGF in regulating peptide expression were examined in vivo in adult rat primary sensory neurons. The hypothesis that NGF might tonically inhibit expression of some peptides was tested specifically. In situ hybridization and immunohistochemistry were used to detect presence or absence of $\alpha$-CGRP, $\beta$-CGRP, SP, SOM, VIP, CCK, NPY, and GAL as well as their mRNAs. In neurons in normal lumbar DRG $\alpha$-CGRP, $\beta$-CGRP, SP, and SOM are abundantly and heterogeneously expressed whereas few neurons have detectable VIP, CCK, NPY, or GAL. Two weeks following sciatic nerve transection, concentrations of $\alpha$-CGRP, $\beta$-CGRP, SP, and SOM plus their mRNAs have decreased to background in all but a few neurons. In contrast, VIP, CCK, NPY, and GAL are now synthesized in many neurons. Delayed intrathecal infusion of NGF (125 $\mathrm{ng} / \mu \mathrm{l} / \mathrm{hr}$ ) for $7 \mathrm{~d}$, starting 2 weeks after injury counteracted the decrease in expression of $\alpha$-CGRP, $\beta$-CGRP and SP expression, but not SOM. This lack of influence of NGF on SOM is consistent with the absence of high-affinity NGF receptors and trk mRNA in SOM-positive neurons. Delayed infusion of NGF also reduced the number of neurons expressing VIP, CCK, NPY, and GAL after injury by approximately one-half in each subpopulation. Therefore, we suggest that NGF suppresses expression of these four peptides but only if the neurons also have NGF receptors. The results show that NGF can regulate peptide expression differentially and may also be part of the signal that allows reversion to normal of responses to injury as axons regenerate.

[Key words: dorsal root ganglion, axotomy, neurotrophin, plasticity, trk, mRNA]

When a peripheral sensory neuron is injured, profound cytochemical, functional, and morphological changes in the proximal and distal portions of the neuron ensue (Lieberman, 1974; Grafstein and McQuarrie, 1978; Grafstein, 1983; Aldskogius, 1985).

Received Apr. 15, 1994: revised Sept. 6, 1994; accepted Sept. 14, 1994.

This work was supported by the Canadian and Swedish Medical Research Councils (MRCs). V.M.K.V. was supported by a Canadian MRC Fellowship and now an MRC. Scholarship. We thank Dr. L. Terenius, Karolinska Institutet, for generously supplying the SP and NPY antisera used in these studies.

Correspondence should be addressed to Valerie M. K. Verge, University of Saskatchewan, Department of Anatomy, College of Medicine, Saskatoon, Saskatchewan, Canada, S7N 0W0.

Copyright (C) 1995 Society for Neuroscience $0270-6474 / 95 / 152081-16 \$ 05.00 / 0$
In this state, the cell body's primary role shifts from one of neurotransmission to one which focuses on surviving the insult and mounting a vigorous regeneration program (Liebermann, 1971; Barron, 1983; Greenberg and Lasek, 1988; Hoffman and Cleveland, 1988; Moskowitz et al., 1993). Responses to axotomy include dramatic changes in expression of peptides which modify sensory function and serve as indicators of the physiologic state of the neuron (Henry, 1976; Salt and Hill, 1983; Wiesenfeld-Hallin et al., 1989a,b, 1990, 1992a; Verge et al., 1993a; Xu et al., 1993). Sciatic nerve transection causes a marked decrease in substance P (SP) (Jessell et al., 1979; Tessler et al., 1985), somatostatin (SOM) (Noguchi et al., 1993), and both $\alpha$ - and $\beta$-calcitonin gene related peptide (CGRP) (Shehab and Atkinson, 1986a; Noguchi et al., 1990) in lumbar DRGs. In contrast, dramatic upregulation of vasoactive intestinal peptide (VIP) (Shehab and Atkinson, 1986a,b; Nielsh et al., 1989; Noguchi et al., 1989; Villar et al., 1989), galanin (GAL) (Hökfelt and Keen, 1987; Villar et al., 1989), neuropeptide tyrosine (NPY) (Wakisaka et al., 1992; Zhang et al., 1993), and cholecystokinin (CCK) peptides (Verge et al., 1993b) are observed in the same ganglia.

Although the exact signals which mediate the axotomy response are poorly understood (Cragg, 1970; Aldskogius et al., 1992), many of the changes in peptide expression following injury are thought to be initiated by a reduction in the normal retrograde transport of trophic molecules derived from the endoneurium or target (Raivich et al., 1991). In support of this hypothesis, blockade of axonal transport in otherwise normal animals is sufficient to induce expression of VIP and GAL and reduce that of CGRP, changes normally observed after lesion (Knyihar-Csillik et al., 1991; Kashiba et al., 1992). One such retrogradely derived trophic molecule is NGF and it has served as the prototypical neurotrophin (NT) due to its ready availability. NGF, initially characterized for its effect on sensory neurite outgrowth (Levi-Montalcini and Angeletti, 1968) is produced in limited quantities by peripheral tissues (Korsching and Thoenen, 1983; Shelton and Reichardt, 1984; Goedert et al., 1986). NGF mediates its effects on primary sensory neurons by binding to high-affinity receptors expressed by approximately $40 \%$ of adult rat primary sensory neurons (Richardson et al., 1986; Verge et al., 1989a, 1992a), after which it is internalized and retrogradely transported to the cell body (Stoeckel et al., 1975; Goedert et al., 1981; Richardson and Riopelle, 1984). During development NGF appears necessary for survival of small diameter sensory 
neurons projecting to laminae I and II of the dorsal horn, presumably subserving nociception and thermoreception (Ruit et al., 1992) as evidenced by a severe deficit in these sensory functions in mice with a null mutation in the gene encoding trk, the signal transducing receptor for NGF (Smeyne et al., 1994). NGF also influences the appropriate phenotypic development and regulation of cutaneous high threshold mechanoreceptors (Ritter et al., 1991; Ritter and Mendell, 1992). In adult rat, the major role for NGF shifts from dependency for survival (Gorin and Johnson, 1980; Lindsay, 1988; Schwartz et al., 1982; Carroll et al., 1992; Lewin et al., 1992; Ruit et al., 1992) to maintenance of differentiated phenotype, best exemplified by the ability of exogenous NGF to counteract loss of SP and CGRP following injury (Fitzgerald et al., 1985; Inaishi et al., 1992) and to regulate their expression in vitro (Lindsay and Harmar, 1989; Lindsay et al., 1989). Indeed, virtually all neurons expressing SP and most expressing CGRP, display high-affinity NGF receptors and are thus presumably responsive to NGF, while somatostatinergic neurons do not (Verge et al., 1989b). This tight colocalization with specific peptidergic subpopulations suggests functions for endogenous NGF in regulation of peptide synthesis within these NGF-responsive neurons.

The present study demonstrates at a cellular level, the extent to which NGF may he involved in the plasticity of peptide expression observed in sensory neurons after sciatic nerve injury. More specifically, a role for NGF in peptide suppression was addressed by examining whether exogenous application of NGF following injury might be able to downregulate expression of injury-induced peptides. Results show that delayed intrathecal infusion of NGF counteracted injury-induced decreases in SP, $\alpha$-CGRP, and $\beta$-CGRP expression, but not SOM. They also suggest a potential in vivo role for NGF in peptide suppression, as exemplified by the ability of the NGF infusion to mitigate expression of the injury-induced peptides GAL, NPY, VIP, and CCK.

This work has been previously reported in abstract form (Verge et al., 1992b).

\section{Materials and Methods}

Animal surgery. Experiments were performed on adult Sprague-Dawley rats of either sex weighing approximately $200 \mathrm{gm}$ and anesthetized for surgery using sodium pentobarbital $(50 \mathrm{mg} / \mathrm{kg})$ or choral hydrate $(350$ $\mathrm{mg} / \mathrm{kg}$ ) intraperitoneally. In all rats, the right sciatic nerve was transected at its origin from the L4 and L5 spinal nerves and a $5 \mathrm{~mm}$ segment resected so as to inhibit regeneration. Sixteen of the rats were infused with $\beta-N G F$, prepared from mouse submandibular glands by cation exchange chromatography (Longo et al., 1989), for 1 week following a 2 week injury period. Infusion of NGF was via mini osmotic pumps (Alza, 2001) inserted into the dorsal lumbar subcutaneous space and attached to silicon tubing $(0.3 \mathrm{~mm}$ o.d. $)$ which was passed through the dura and arachnoid at the lumbosacral junction so that a $1.5 \mathrm{~cm}$ segment lay intrathecally. NGF was delivered at $125 \mathrm{ng} / \mu \mathrm{l} / \mathrm{hr}$ in a soIution of phosphate buffered saline containing rat serum albumin $(1 \mathrm{mg} /$ $\mathrm{ml})$, streptomycin $(100 \mathrm{U} / \mathrm{ml})$ and penicillin $(100 \mathrm{U} / \mathrm{ml})$. Five rats were infused with vehicle alone, while an additional 16 rats underwent 2 week sciatic nerve transection alone. Special care was always taken to assure the sterility of the pump contents and the silicon tubing. In order to examine the plasticity of peptide expression within subpopulations of DRG neurons, six rats underwent only a $2-3$ d injury period. Rats were allowed to survive for the designated transection periods or transection plus delayed infusion of NGF or vehicle before processing for either in situ hybridization or immunohistochemistry as described below.

Preparation of probes. Oligonucleotide probes complimentary to and selective for the following mRNAs were synthesized: rat GAL, base pairs 152-199 (Vrontakis et al., 1987); rat VIP, base pairs 347-394 (Nishizawa et al., 1985); rat CCK, base pairs 298-341 (Deschènes et al., 1984); rat SOM, nucleotides encoding aa 97-107 (Goodman et al., 1983); rat NPY, base pairs 1671-1714 (Larhammar et al., 1987); rat SP, base pairs 145-192 (Krause et al., 1987); rat $\alpha$-CGRP, base pairs 664698 (Amara et al., 1985); rat $\beta$-CGRP, base pairs 656-690 (Amara et al., 1985); rat GAP43, base pairs 70-117 (Karns et al., 1987); and rat trk, which is the counterpart of base pairs $1198-1245$ of the human trk sequence (Merlio et al., 1992; Meakin et al., 1992). Oligonuclcotides probes were synthesized in an Applied Biosystems DNA synthesizer 381 A (Foster City) and purified through OPC-columns (Applied Biosystems, USA) or synthesized by Scandinavian Gene Synthesis (Koping, Sweden). The probes were labeled at the $3^{\prime}$-end with $\alpha-{ }^{35}$ S-dATP (New England Nuclear, Boston) using terminal deoxynucleotidyltransferase (Amersham, UK) in a buffer containing $10 \mathrm{~mm} \mathrm{CoCl}, 1 \mathrm{~mm}$ dithiothreitol (DTT), $300 \mathrm{~mm}$ Tris base, and $1.4 \mathrm{~m}$ potassium cacodylate ( $\mathrm{pH}$ 7.2), purified through NFNSORB-20 columns (New Fngland Nuclear) and DTT added to a final concentration of $7 \mathrm{~mm}$. The specific activities obtained ranged from 2 to $5 \times 10^{6} \mathrm{cpm} / \mathrm{ng}$ oligonucleotide.

In situ hybridization. Deeply anaesthetized animals were perfused via aorta with $50 \mathrm{cc}$ of $\mathrm{Ca}^{2+}$ free Tyrode's solution. Right and left L4 and L5 lumbar dorsal root ganglia were rapidly dissected and frozen in OCT Compound (Tissue Tek, Miles Laboratories, USA) in a Cryomold (Iissue Tek, Miles Laboratories, USA). Before sectioning, blocks containing pairs of dorsal root ganglia from control and experimental groups were juxtaposed and fused by OCT compound to ensure processing of both groups under identical conditions. Sections were cut at $5 \mu \mathrm{m}$ on a Micron cryostat (Zeiss, Germany), thaw mounted onto Probe-ON slides (Fisher Scientific, USA), and stored with desiccant at $-20^{\circ} \mathrm{C}$ until hybridization.

Hybridization was carried out according to published procedures (Dagerlind et al., 1992). The sections were brought to room temperature, air dried and, without any additional treatment, covered with a hybridization buffer containing $50 \%$ formamide (J. T. Baker Chemicals, Netherlands) $4 \times$ SSC $(1 \times$ SSC: $0.15 \mathrm{M} \mathrm{NaCl}, 0.015 \mathrm{M}$ sodium citrate $), 1$ $\times$ Denhardt's solution $(0.02 \%$ bovine serum albumin and $0.02 \%$ Ficoll $)$, $1 \%$ sarkosyl ( $N$-laurylsarcosine), $0.02 \mathrm{M}$ phosphate buffer (pH 7.0), $10 \%$ dextran sulfate, $500 \mathrm{mg} / \mathrm{ml}$ heat-denatured salmon testis DNA, $200 \mathrm{~mm}$ DTT, and $10^{7} \mathrm{dpm} / \mathrm{ml}$ of probe. The slides were placed in a box humidified with $50 \%$ formamide and incubated at $42^{\circ} \mathrm{C}$ for $18 \mathrm{hr}$. After hybridization, the slides were washed four times for $15 \mathrm{~min}$ in $1 \times \mathrm{SSC}$ at $55^{\circ} \mathrm{C}$ and then brought to room temperature over $30 \mathrm{~min}$ while in the final rinse, dipped twice in distilled water, dehydrated in $60 \%$ and 95\% ethanol, and dried with an airstream.

To generate radioautograms, the incubated slides were dipped in NTB2 nuclear track emulsion (Kodak, USA) diluted 1:1 with distilled water and stored in the dark with desiccant at $-20^{\circ} \mathrm{C}$. The sections were exposed for 2-4 weeks, and then developed in Kodak D19 for 3 min, fixed, and mounted with glycerol and a coverslip for analysis on a Nikon Microphot-FX microscope equipped with dark-field condenser or stained with Toluidine blue, mounted with Entallan (Merck, Germany) and a coverslip for viewing under bright field.

Analysis. Quantitative and qualitative analysis of NGF effects on peptide expression in injured neurons was conducted only on series of sections from fused experimental and control ganglia with virtually all axons transected as indicated by a strong upregulation of GAP43 mRNA (see Fig. 8), a well-known marker of peripheral nerve injury in sensory neurons (Skene and Willard, 1981; Tetzlaff et al., 1989; Van der Zee et al., 1989; Verge et al., 1990a) in order to avoid the occurrence of false-positives and -negatives. A few neurons appeared to be spared the lesion and are believed to be some of those contributing to the dorsal cutaneous nerve. Counts were performed under $100 \times$ oil immersion on sections from L5 DRG stained with toluidine blue from three separate NGF-infused rats paired with those with injury only. Cells were considered labeled if they had more than five times background levels of silver grains, as determined by averaging grain counts over defined areas of the neuropil devoid of positively labeled cell bodies. Percentages were determined by dividing the number of labeled neurons by the total number of toluidine blue stained neurons in a section.

Identification and characterization of a peptidergic subpopulation of neurons which express VIP after injury. Photomontages of serial $5 \mu \mathrm{m}$ L5 DRG sections from $3 \mathrm{~d}$ injured rats and processed for in situ hybridization to detect SP, VIP, and SOM mRNAs were prepared and individual labeled neurons identified in the serial sections. Presence of radiolabel in the neurons was confirmed under $100 \times$ oil immersion. Coexpression of SOM and trk mRNAs was also examined using the 
same approach on serial sections of L5 DRG associated with intact sciatic nerve.

In situ hybridization control experiments. The specificity of hybridization signal for each probe used in the study was ascertained by hybridization of adjacent $10 \mu \mathrm{M}$ sections of paired L5 ganglia from a rat with a $14 \mathrm{~d}$ right sciatic nerve injury. Series of sections were hybridized with either labeled probe, labeled probe with a 400-fold excess of cold probe, or labeled probe with a 400 -fold excess of another, dissimilar cold probe of the same length and similar G-C content. In addition, all sequences of oligonucleotide probes were checked against all GenBank entries just prior to submission of the article to verify that they still had no greater than $65 \%$ homology with any known sequence. The stringency used for in situ experiments were such that homologies greater than $90 \%$ are required for hybridization of probe to transcript to remain following the washes (Dagerlind et al., 1992)

Immunohistochemistry. Deeply anesthetized animals were perfused via the aorta with warm $37^{\circ} \mathrm{C} \mathrm{Ca}^{2+}$-free Tyrode's solution followed by a fixative containing $4 \%$ paraformaldehyde and $0.2 \%$ picric acid in 0.16 M phosphate-buffered saline (PBS; Pease, 1962; Zamboni and De Martino, 1967) for $6 \mathrm{~min}$. The right and left L4 and L5 DRG were quickly dissected out, postfixed for $30 \mathrm{~min}$ in the same fixative, and immersed in $10 \%$ sucrose solution containing $0.01 \%$ sodium azide and $0.02 \%$ bacitracin (Bayer, Germany) overnight. Paired experimental and control ganglia were mounted in the same cryomold (to ensure processing under identical conditions), covered with OCT compound and frozen in cooled isopentane. Transverse $14 \mu \mathrm{m}$ sections were cut on the cryostat and processed according to the indirect immunofluorescence technique of Coons and colleagues (see Coons, 1958). Briefly, the sections were rehydrated in $0.1 \mathrm{M}$ PBS and then incubated overnight at $4^{\circ} \mathrm{C}$ in a humid chamber with either polyclonal rabbit antisera against Gal (1:400; Peninsula, USA), SP or NPY (1:400; kindly provided by Dr. L. Terenius) or mouse monoclonal antisera against CGRP $(1: 400$, Celltech, UK) or SOM (1:400 Buchan et al., 1985). After several rinses in PBS, the sections were incubated with either fluorescein isothiocyanate (FITC)conjugated goat anti-rabbit antibodies (1:80, Boehringer Mannheim, Germany) or sheep anti-mouse antibodies (1:10, Amersham), respectively. The sections were mounted with a mixture of glycerol and PBS $(3: 1)$, containing $0.1 \% p$-phenylenediamine in order to retard fading (Platt and Micheal, 1983) and a coverslip and examined on a NikonMicrophot-FX microscope.

The specificity of peptide antisera was tested by absorption with their cognate synthetic peptides (Peninsula, USA) at a concentration of $1 \mu \mathrm{M}$ for $24 \mathrm{hr}$ at $4^{\circ} \mathrm{C}$, followed by immunohistochemistry.

\section{Results}

In situ hybridization-nerve injury and NGF infusion

Figures 1, 2, 4, 5, and 8 are all from the same experimental and control animal series so as to qualitatively demonstrate the effect of nerve injury with and without NGF infusion on the full range of peptides without concern for animal to animal variations.

In intact neurons of DRG contralateral to injury $\alpha$-CGRP, SP and SOM mRNAs were abundantly and heterogeneously expressed, while a lower level of hybridization signal for $\beta$-CGRP was also readily detectable in many neurons (Figs. 1, 2). Only a few small neurons in these ganglia were seen to express GAL mRNA and only the rare neuron expressed detectable VIP, CCK or NPY mRNAs (Figs. 4, 5).

Two weeks after sciatic nerve injury labeling with SP, $\alpha$-CGRP, $\beta$-CGRP, and SOM probes in ipsilateral L5 DRG was consistently diminished to background grain levels in all but a few neurons (Figs. 1, 2). The diminution was evident as early as $2 \mathrm{~d}$ after injury and continued for at least 9 weeks (data not shown). In contrast, VIP, CCK, NPY, and GAL mRNA hybridization signal was dramatically upregulated in many neurons (Figs. 4, 5).

Delayed infusion of NGF for 1 week following the 2 week injury period counteracted the decrease in $\alpha$-CGRP, $\beta$-CGRP, and SP expression in the injured neurons (Figs. 1,2), but did not appear to influence the SOM population (Fig. 2). Normally approximately $10 \%$ of the intact neurons expressed SOM
mRNA. Two weeks after injury the occasional SOM mRNApositive neuron was observed on ganglia ipsilateral to lesion in both infused and noninfused animals, representing $<1 \%$ of the total remaining neurons. Whether this expression was in the few neurons spared from the lesion was not determined; however, similar low numbers of neurons expressing SP and CGRP were also observed in ganglia ipsilateral to lesion. Intrathecal infusion of NGF also appeared to increase concentrations of SP, $\alpha$-CGRP and $\beta$-CGRP to supranormal in contralateral uninjured ganglia (Figs. 1, 2). More notably, exogenous NGF mitigated injuryinduced increases in GAL, NPY, VIP, and CCK mRNAs (Figs. $4,5)$. The quantification of this effect is shown in Table 1. The reduction in detectable mRNA peptide expression following NGF treatment was most evident in the GAL subpopulation. Similar but smaller reductions in the numbers of injured neurons expressing detectable NPY, VIP, and CCK mRNAs, were also recorded. Thus, it would appear that NGF infusion effected a downregulation in peptide expression in neurons that represent approximately one-half of injured neurons normally expressing each of these peptide mRNAs. This pattern of downregulation of peptide expression in some neurons after NGF infusion was apparent in all NGF-infused animals examined, with the exception of one animal in whom the intrathecal catheter was found to lie outside the intrathecal space at the time of sacrifice. Also, the ability of NGF to downregulate peptide expression was not complete because some neurons still displayed abundant hybridization signal for GAL, NPY, CCK, and VIP as though not influenced by the infusion (Figs. 4, 5).

In order to speculate that the inability of NGF to downregulate injury-induced peptide expression in some injured neurons is linked to the expression of these peptides in neurons which do not display receptors for NGF, it was necessary to demonstrate the expression of the peptide in a subpopulation of neurons which normally do not respond to NGF. Thus, neuronal peptide expression was examined shortly after axotomy while peptide expression is still in a state of dramatic changes in expression. At this point peptides normally abundantly expressed in intact neurons are being downregulated and those whose expression is upregulated in response to the injury are now at detectable levels. Figure $7 A-D$ shows VIP mRNA expression to be upregulated in neurons still expressing detectable levels of SP or SOM hybridization signal $3 \mathrm{~d}$ after injury, the former being expressed in NGF-responsive neurons, while the latter is not (Verge et al., 1989b). SOM and SP expression did not appear to colocalize (data not shown). A lack of high-affinity NGF receptor expression in SOM neurons was confirmed in that a lack of coexpression of detectable SOM and trk mRNAs was observed in 52 SOM neurons examined in adjacent sections of L5 DRG from normal rats (Fig. $7 E, F$ ).

None of the above mentioned effects of NGF infusion were observed in animals with unilateral transection followed by vehicle infusion when compared to their paired counterparts with only unilateral transection (data not shown). Hybridization control experiments showed all specific hybridization signal to be abolished in the presence of labeled probe plus a 400 -fold excess of unlabeled probe, while no change in hybridization pattern was observed when a 400 -fold excess of a dissimilar probe of equal length and similar G-C content was added (Fig. 8E-G).

\section{Immunohistochemistry-nerve injury and NGF infusion}

The immunohistochemical analyses were entirely consistent with in situ hybridization results. Intensely stained SP- and CGRP- 
2084 Verge et al. $•$ Differential Regulation of Neuropeptides by NGF
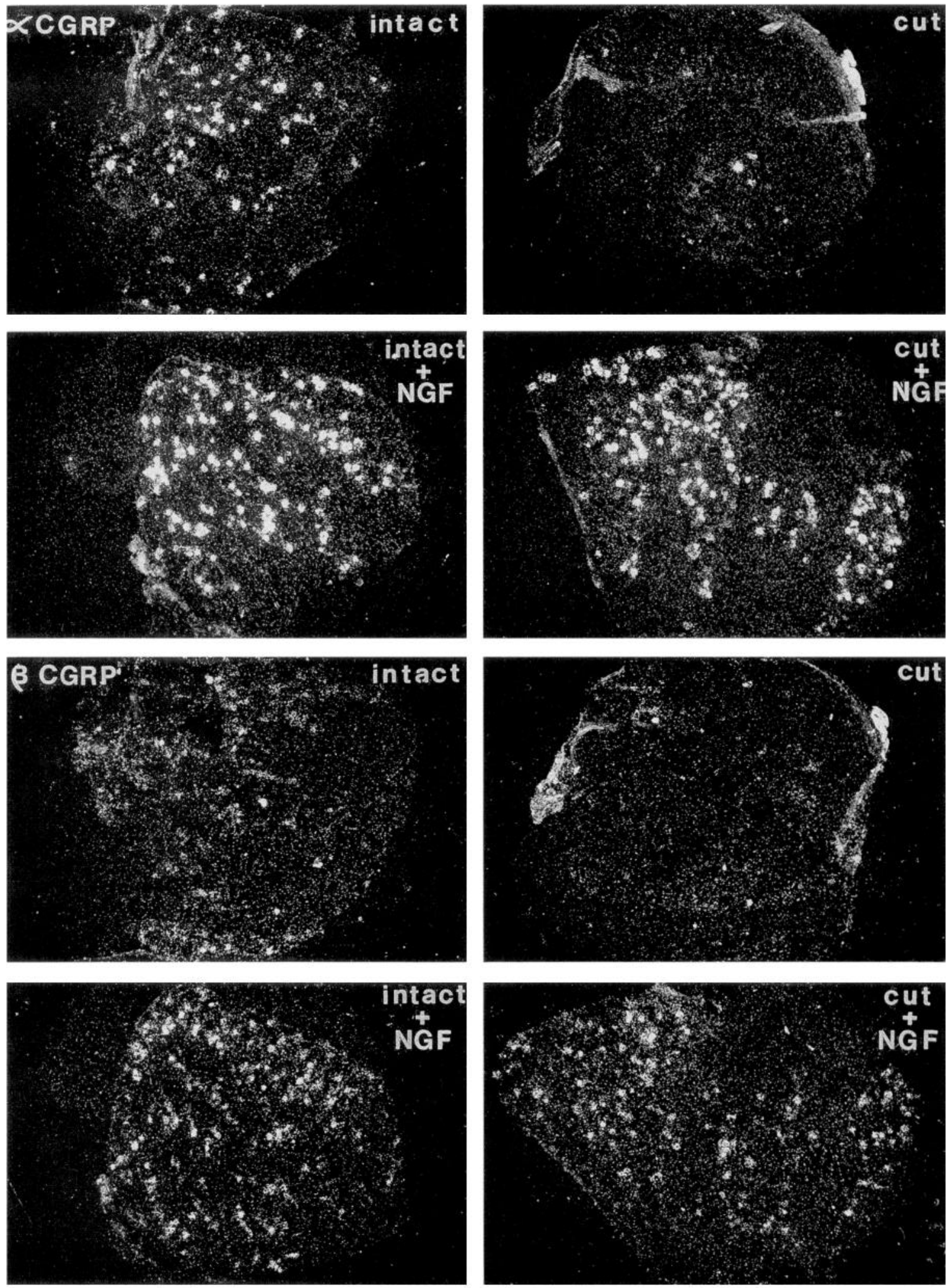

Figure 1. Dark-field photomicrographs of $\mathrm{L}_{5}$ DRG sections processed for in situ hybridization using probes as indicated in the upper left corner of each grouping of four photomicrographs. In intact DRG, many neurons express $\alpha$-CGRP and $\beta$-CGRP mRNA. Two weeks after injury, the expression of $\alpha$-CGRP and $\beta$-CGRP is downregulated. Delayed intrathecal infusion of NGF for $7 \mathrm{~d}, 2$ weeks after injury, was effective in counteracting the decrease in neuronal expression for these two peptides and also increased levels in DRG neurons contralateral to lesion. Magnification, $35 \times$. 

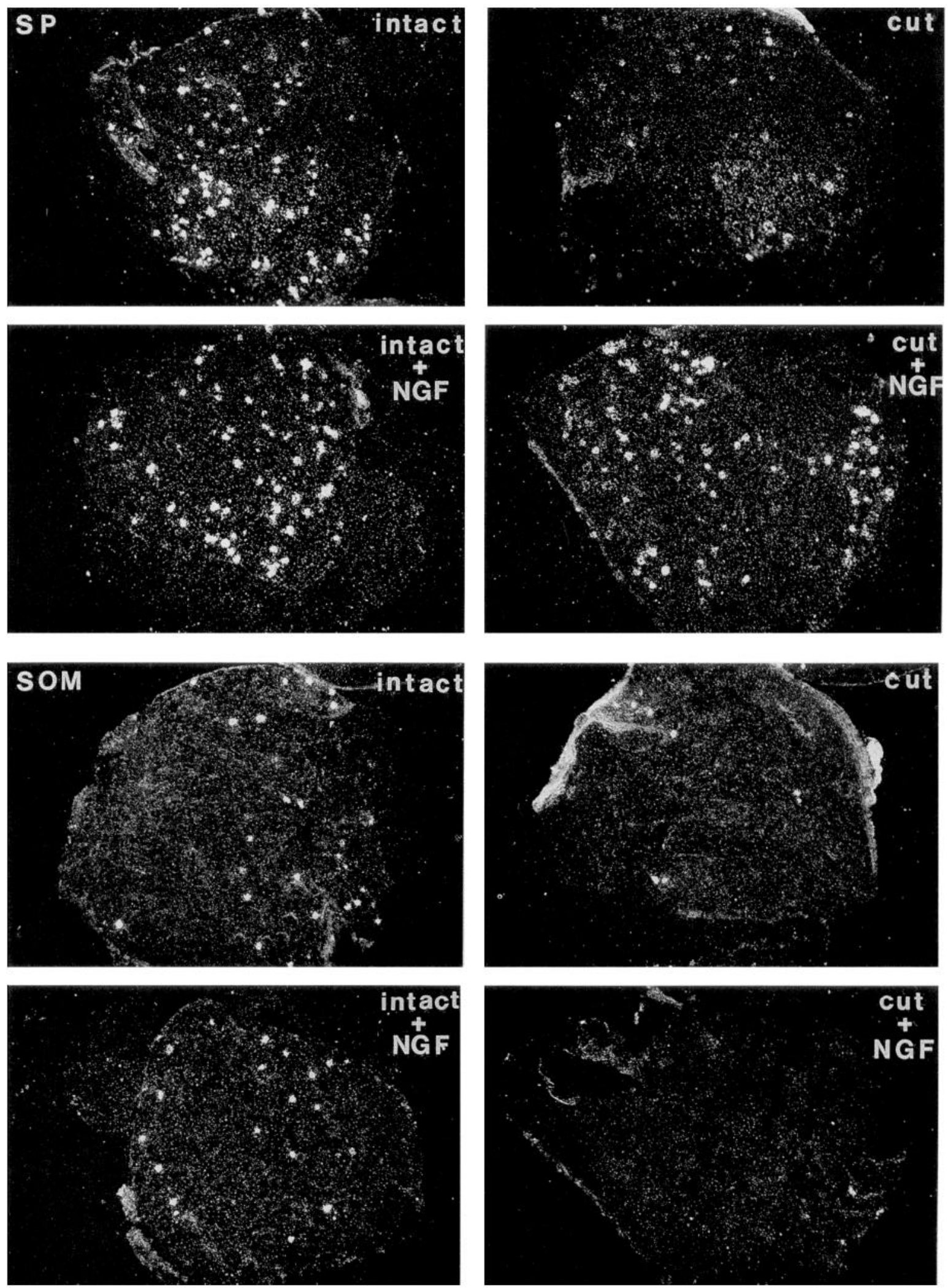

Figure 2. Dark-field photomicrographs of $\mathrm{L}_{5}$ DRG sections processed for in situ hybridization using probes as indicated in the upper left corner of each grouping of four photomicrographs. In intact DRG, SP and SOM mRNA are abundantly and heterogeneously expressed. Two weeks after injury, the expression of SP and SOM is downregulated. Delayed intrathecal infusion of NGF for $7 \mathrm{~d}, 2$ weeks after injury, was effective in counteracting the decrease in expression of SP mRNA, but did not appear to influence SOM mRNA. Magnification, $35 \times$. 

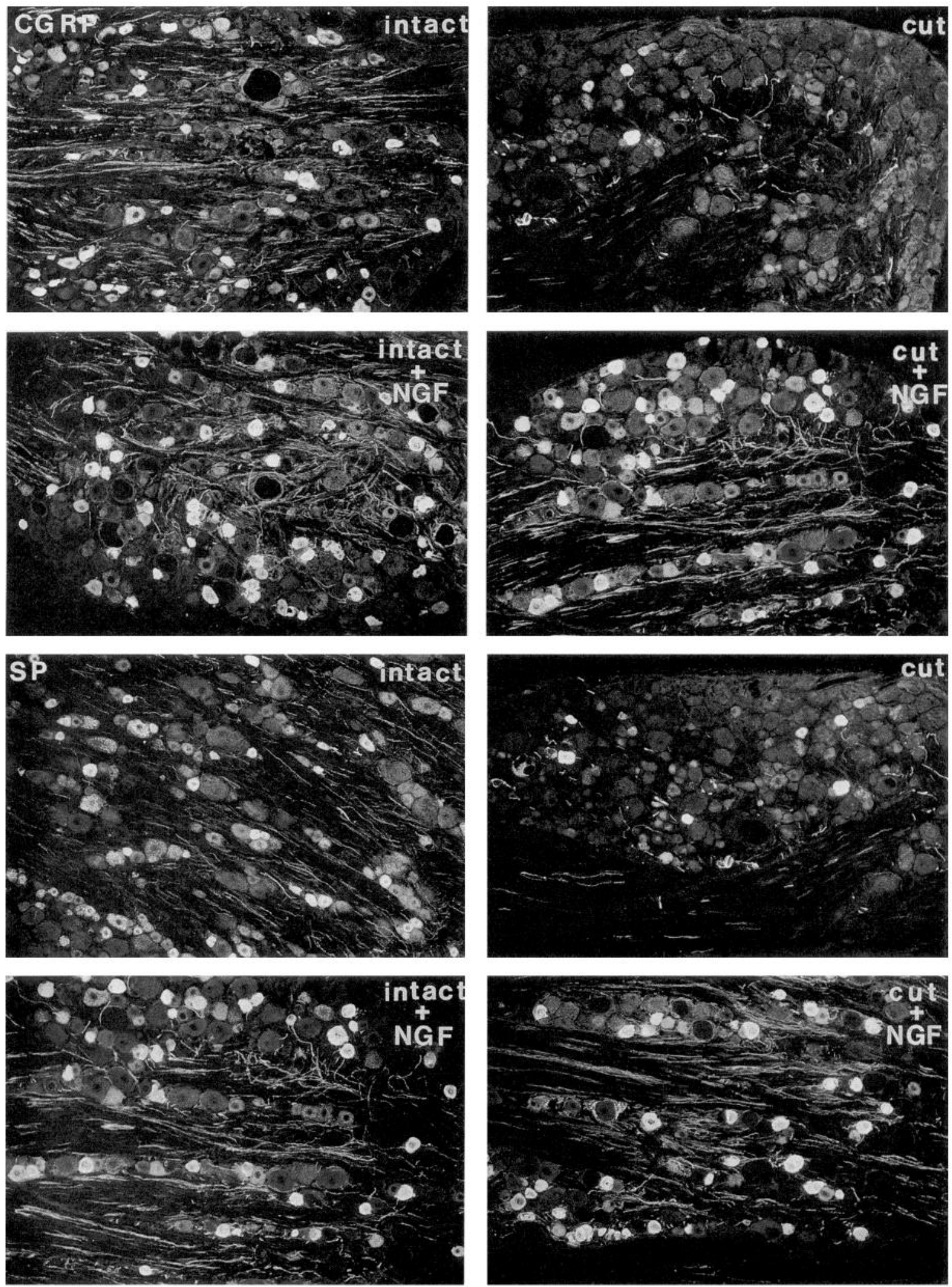

Figure 3. Immunofluorescence micrographs of $\mathrm{L}_{5}$ DRG sections incubated with antisera as indicated in the upper left corner of each grouping of four photomicrographs. In intact DRG, many neurons express CGRP or SP. Two weeks after injury, the expression of CGRP and SP is downregulated in many neurons. Delayed intrathecal infusion of NGF for $7 \mathrm{~d}, 2$ weeks after injury, was effective in counteracting the downregulation of these two peptides as indicated by the increased number of immunopositive neurons. Magnification, $75 \times$. 

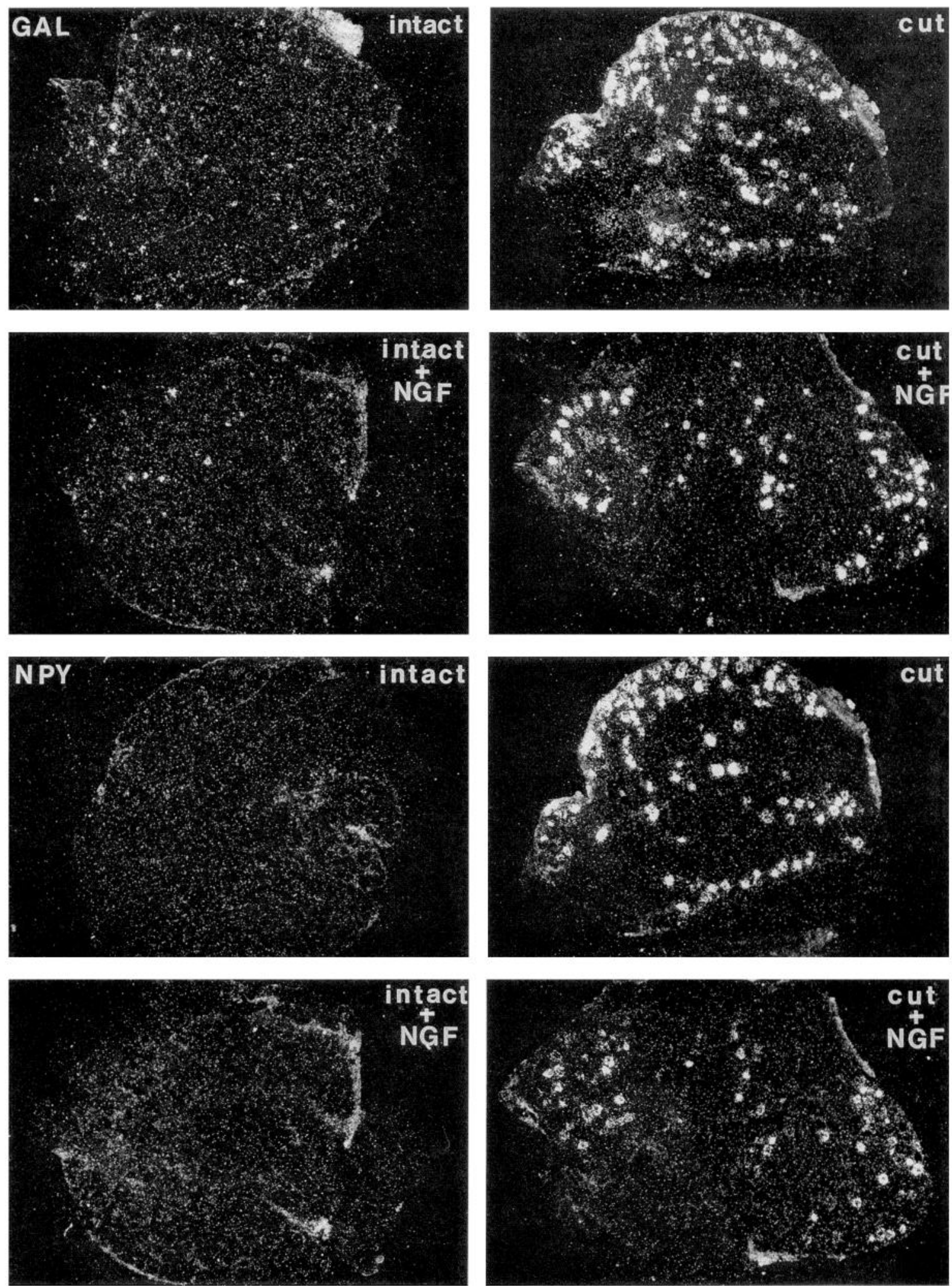

Figure 4. Dark-field photomicrographs of $\mathrm{L}_{5}$ DRG sections processed for in situ hybridization using probes as indicated in the upper left corner of each grouping of four photomicrographs. In intact DRG, few neurons express GAL and NPY mRNA. Two weeks after injury, the expression of GAL and NPY is upregulated in many neurons. Delayed intrathecal infusion of NGF for $7 \mathrm{~d}, 2$ weeks after injury, was effective mitigating the injury-induced increases in mRNA expression for these two peptides, as indicated by the reduction in neurons now expressing detectable message. Magnification, $35 \times$. 

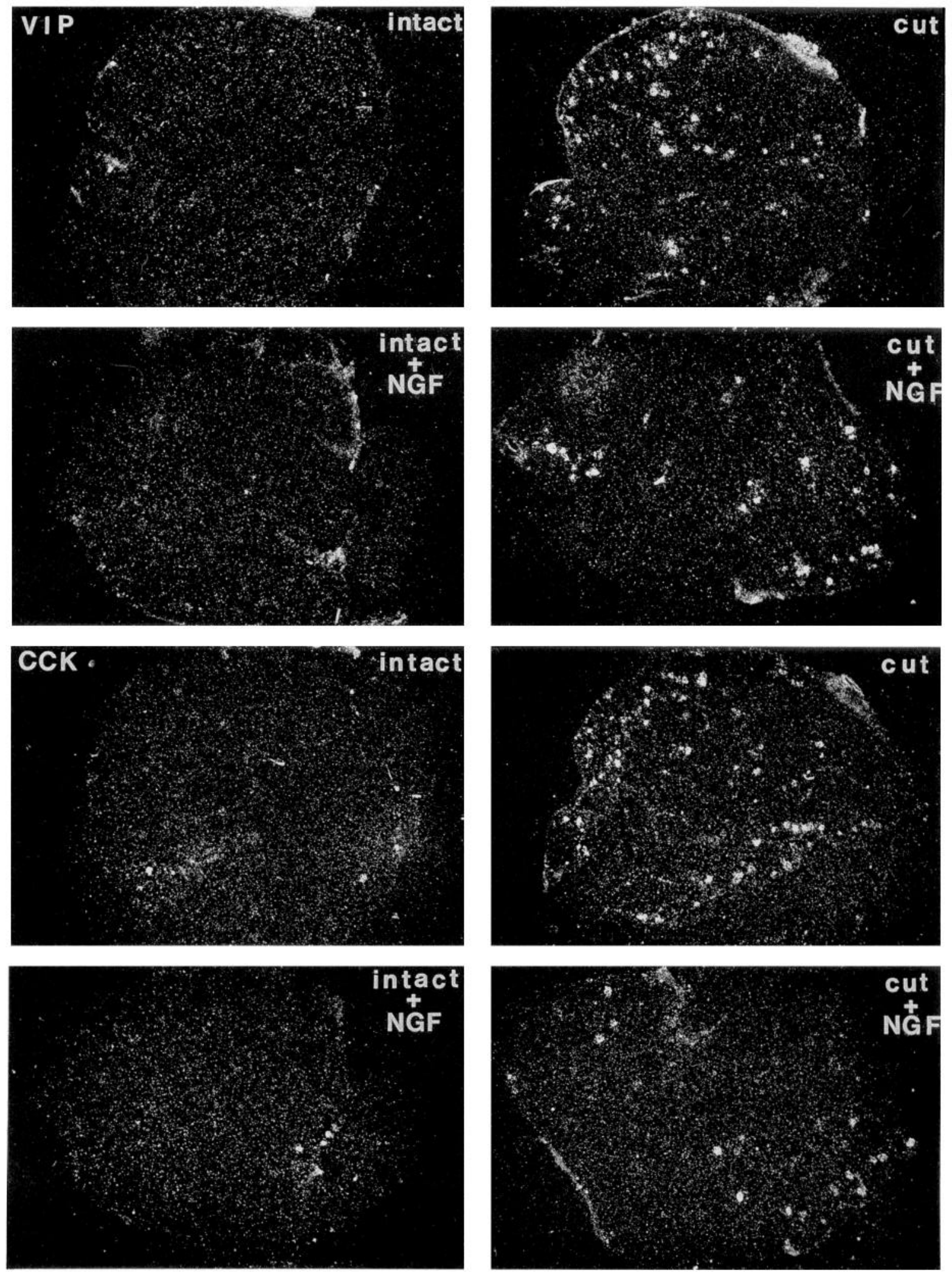

Figure 5. Dark-field photomicrographs of $\mathrm{L}_{5}$ DRG sections processed for in situ hybridization using probes as indicated in the upper left corner of each grouping of four photomicrographs. In intact DRG few neurons express VIP and CCK mRNA. Two weeks after injury, the expression of VIP and CCK is upregulated in many small to medium sized neurons. Delayed intrathecal infusion of NGF for $7 \mathrm{~d}, 2$ weeks after injury was effective mitigating the injury-induced increases in mRNA expression for these two peptides, as indicated by the reduction in neurons now expressing detectable message. Magnification, $35 \times$. 
Table 1. Effects of delayed NGF infusion on numbers of neurons expressing detectable levels of mRNA for injury-induced peptides

\begin{tabular}{cll} 
Series & $\%$ Cut & $\%$ Cut + NGF \\
\hline GAL i & $77(251 / 327)$ & $41(115 / 282)$ \\
ii & $79(335 / 424)$ & $30(110 / 365)$ \\
iii & $78(318 / 410)$ & $47(204 / 437)$ \\
NPY i & $51(142 / 281)$ & $26(73 / 286)$ \\
ii & $47(200 / 423)$ & $29(110 / 369)$ \\
iii & $47(151 / 319)$ & $26(102 / 399)$ \\
VIP i & $30(84 / 281)$ & $14(38 / 268)$ \\
ii & $38(181 / 468)$ & $14(45 / 318)$ \\
iii & $33(106 / 324)$ & $16(66 / 402)$ \\
CCK i & $20(71 / 364)$ & $8(24 / 297)$ \\
ii & $15(69 / 465)$ & $5(17 / 363)$ \\
iii & $17(69 / 417)$ & $8(30 / 397)$ \\
\hline
\end{tabular}

Data are percentages of neurons in paired individual sections of 2 week injured DRG (cut) or 2 week injured DRG followed by one week of NGF infusion (cut + NGF) expressing detectable levels of peptide mRNA as indicated in far left column, with raw counts in parentheses. Effects of injury or injury plus infusion were quantified on slides hybridized to detect mRNAs for each of the injury-induced peptides from the same series of ganglia sections (i, ii, iii).

immunoreactive neurons were heterogeneously distributed throughout the intact ganglia with a pronounced decrease in both the number of immunoreactive neurons and intensity of staining in response to sciatic nerve transection (Fig. 3). In contrast, only a few GAL-immunoreactive neurons, primarily small neurons, and only the very occasional NPY-immunoreactive neuron were observed in ganglia contralateral to lesion. However, 2 weeks after sciatic nerve lesion consistent and dramatic increases in GAL and NPY peptide levels were evident, with many neurons ipsilateral to lesion now positively stained (Fig. 6). NPY immunoreactivity was particularly prominent in mostly large and many medium size neurons, while GAL was found in many small, medium, and some large neurons. Delayed infusion of NGF for 1 week following the 2 week injury period counteracted injury-induced decreases in SP and CGRP peptide levels and reduced the number of intensely stained GAL and NPY neurons (Figs. 3, 6). In agreement with the in situ results, NGF infusion did not completely suppress NPY or GAL peptide expression. Individual neurons still immunoreactive for these peptides wcre intensely stained, as though not influenced by the infusion. A lack of GAL immunoreactivity was most evident in small and medium-sized injured neurons following administration of NGF (Fig. 6) as compared to the noninfused ganglia ipsilateral to lesion. There appeared to be no contralateral effect of NGF infusion on GAL and NPY staining; however, SP and CGRP staining in individual neurons was almost always more intense (Fig. 3), consistent with the elevated mRNA levels observed (Figs. 1, 2).

None of the staining described above was observed after incubation with preabsorbed antisera.

\section{Discussion}

This study confirms and extends previous evidence that NGF dynamically regulates peptide expression in adult rat primary sensory neurons in vivo and supports a potential involvement of NGF in suppression of peptide expression.

$N G F$ can differentially influence peptide expression

The finding that delayed infusion of NGF counteracts decreases in SP and $\alpha$-CGRP following nerve transection was predictable from previous in vivo studies on mature rats showing NGF to upregulate SP and $\alpha$-CGRP following injury (Goedert et al., 1981; Csillik at al., 1985; Fitzgerald et al., 1985; Wong and Oblinger, 1991; Inaishi et al., 1992) or anti-NGF to downregulate SP in intact neurons (Schwartz et al., 1982). We know of no sludy prior to this one which has addressed whether the regulation of CGRP by NGF also includes an influence on $\beta$-CGRP expression. This question was particularly intriguing as the expression of $\alpha$-CGRP and $\beta$-CGRP are differentially altered in axotomized spinal motor neurons, which would suggest the involvement of separate regulatory mechanisms in these neurons (Noguchi et al., 1990). However, Figure 1 clearly demonstrates the consistent result that exogenous NGF can reverse injuryinduced decreases in $\beta$-CGRP mRNA following injury and thus it appears that both CGRPs can be regulated in a similar fashion by NGF in sensory neurons. Intrathecal NGF infusion also increased expression of $\alpha$-CGRP, $\beta$-CGRP, and SP to supranormal levels in ganglia contralateral to lesion (Figs. 1-3). This response to NGF has already been described for SP and $\alpha$-CGRP (Goedert et al., 1981; Inaishi et al., 1992). Elevated levels of NGF in inflamed tissue (Weskamp and Otten, 1987; Donnerer et al., 1992) are thought to underlic both the increased levels of peptides observed in sensory afferents in these regions and the ensuing hyperalgesia (Lembeck et al., 1981; Kuraishi et al., 1989; Gillardon et al., 1991; Donaldson et al., 1992; Donnerer et al., 1992). Functional studies employing several approaches have demonstrated that elevated levels of NGF result in profound mechanical hyperalgesia (Taiwo et al., 1991; Davis et al., 1993; Lewin et al., 1993). The long latency observed in development of mechanical hyperalgesia following NGF administration (Lewin et al., 1993) is consistent with initiation of peptide synthesis. Indeed, the two sensory peptides positively regulated by NGF, SP, and CGRP elicit excitatory and algesic effects at the level of the dorsal horn, the former on its own, while CGRP appears to potentiate SP's effects (Wiesenfeld-Hallin et al., 1984; Gamse and Saria, 1986; Weisenfeld-Hallin, 1986; Woolf and Wiesenfeld-Hallin, 1986; Mao et al., 1992).

The novel finding that the number of injured neurons expressing abundant mRNA for GAL, NPY, VIP, and CCK were dramatically reduced following delayed NGF infusion implicates NGF in the suppression of these peptides in the intact state when there is normal retrograde supply of the neurotrophin back to the neuron. The role of NGF in peptide suppression has not been previously examined in sensory neurons in vivo; however, an in vitro study addressed how NGF might influence VIP expression in mature DRG neurons (Mulderry and Lindsay, 1990). Here NGF was found not to alter VIP levels, a finding previously reported for both SP and VIP expression in cultured sympathetic neurons (Zigmond et al., 1992; Kessler et al., 1981). While it is difficult to reconcile the finding of Mulderry and Lindsay with those of the present study, it is quite possible that the regulation of VIP expression was different in the in vitro model. Only $\sim 35 \%$ of the injured neurons expressed detectable mRNA for VIP following proximal sciatic nerve transection in vivo (Table 1), while in the Mulderry and Lindsay study virtually all the cultured neurons expressed VIP. In addition, proliferation of non-neuronal cells was inhibited, thus eliminating or greatly reducing a potential source of other regulatory molecules (see below).

Exogenous NGF effected a reduction in detectable mRNA cxpression for injury-induced peptides in only approximately half of each representative peptidergic subpopulation. The neu- 

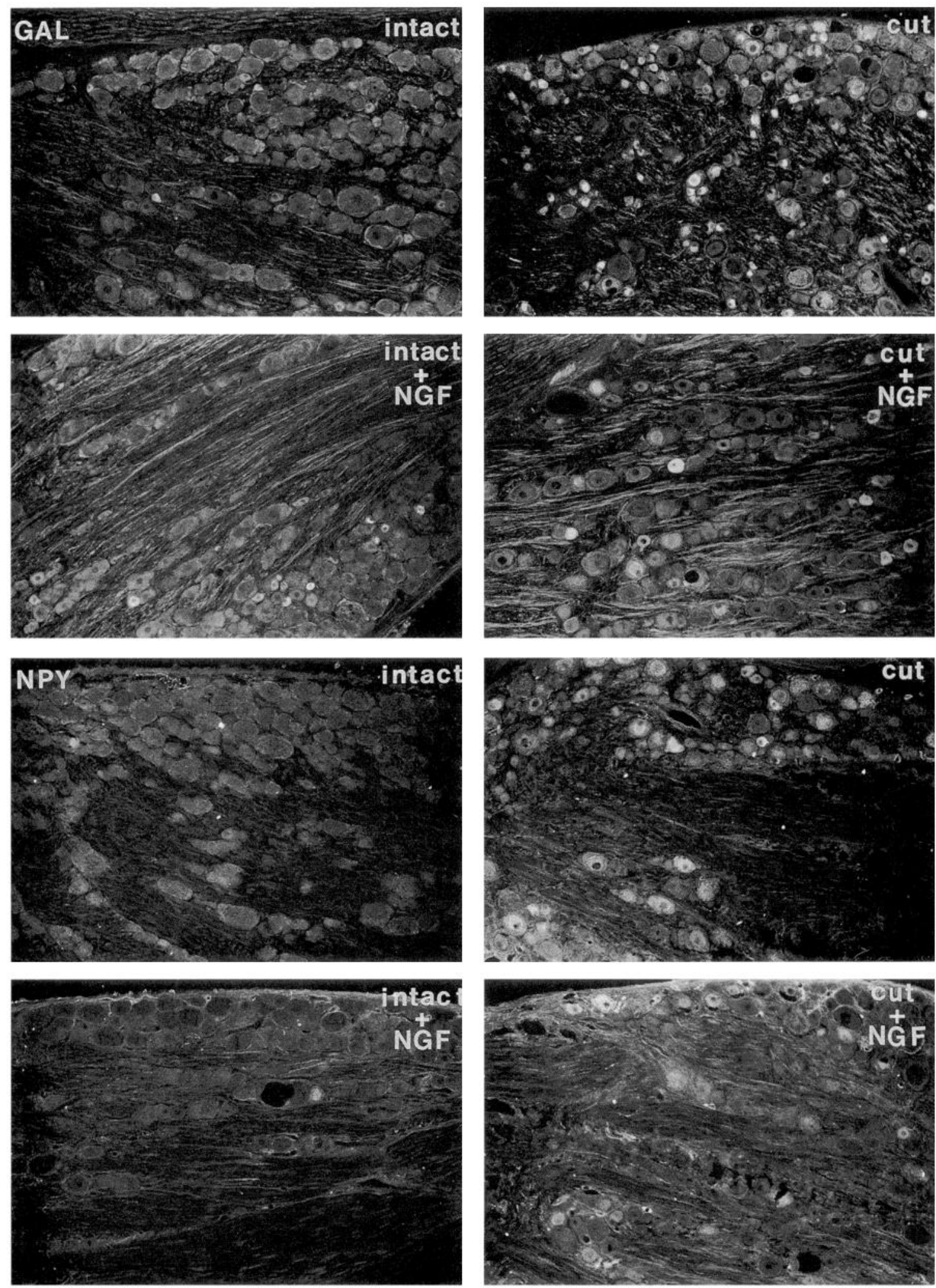

Figure 6. Immunofluorescence micrographs of $\mathrm{L}_{5}$ DRG sections incubated with antiserum as indicated in the upper left corner of each grouping of four photomicrographs. In intact DRG, few neurons express GAL or NPY. Two weeks after injury, the expression of GAL and NPY is upregulated in many neurons. Delayed intrathecal infusion of NGF for $7 \mathrm{~d}, 2$ weeks after injury, was effective in mitigating the injury-induced expression of these two peptides as indicated by the reduced number of immunopositive neurons. Magnification, $75 \times$. 

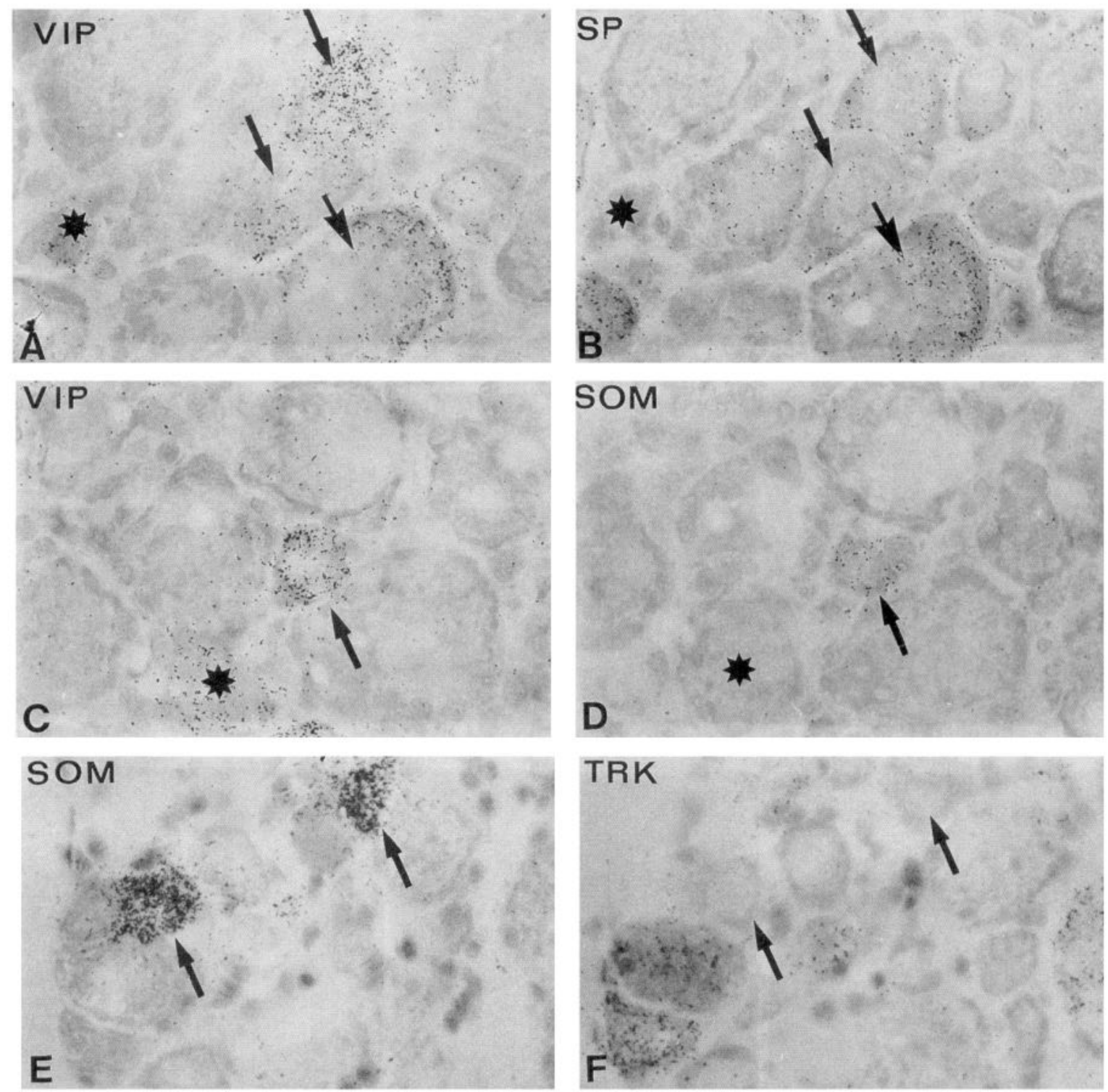

Figure 7. Photomicrographs of $5 \mu \mathrm{m}$ adjacent sections, $A$ and $B, C$ and $D, E$ and $F$, of $\mathrm{L}_{5}$ DRG processed for in situ hybridization with probes as indicated. $A-D$, sections of DRG $3 \mathrm{~d}$ after axotomy show upregulation of VIP expression in some neurons still expressing detectable SP or SOM mRNA (arrows), while others do not (asterisk). $E$ and $F$, Normal DRG sections showing a lack of coexpression of SOM and trk mRNA, an essential component of high-affinity NGF receptors (arrows). Magnification: $A-D, 420 \times ; E$ and $F, 180 \times$.

rons which continued to express these peptides did so in a robust manner as though unaffected by the infusion. We propose that the ability of NGF treatment to influence the injury-induced plasticity in neuronal peptide expression is determined by whether or not the neuron has high-affinity NGF receptors. In past studies employing the same model, it has been shown that exogenous NGF affected gene or protein expression only in neurons displaying high-affinity binding sites (Verge et al., 1989a, 1990b, 1992a), despite the fact that two of the genes examined, namely the low-affinity NGF receptor (LNGFR, p75) and the medium neurofilament subunit, are expressed in many additional DRG neurons lacking high-affinity NGF receptors. We therefore demonstrated, using VIP as an example, that increased VIP mRNA expression three days following injury is in neurons still expressing detectable SP or SOM mRNA, representing NGFresponsive and NGF-unresponsive neurons respectively. That mature SOM neurons are unresponsive to NGF is inferred from the lack of trk mRNA expression (Fig. 7) or high-affinity NGF binding sites (Verge et al., 1989b) and the inability of NGF infusion in this study to counteract the decreases observed in SOM after injury. The lack of NGF influence on SOM neurons is unlikely to be due to the selective death of these neurons following injury. While approximately $20-30 \%$ of adult rat sensory neurons can be expected to die 2-3 weeks following proximal sciatic nerve lesion (Arvidsson et al., 1986; Himes and Tessler, 1989; Verge et al., 1989a), there is no compelling evidence for selective vulnerability of one subpopulation over another (reviewed in Aldskogius et al., 1992). Additionally, at least some SOM neurons appear capable of surviving proximal axotomy. Regeneration studies were conducted with either crush or transection plus resection injuries at the same distance from the ganglia as in this study. In ganglia ipsilateral to lesion, SOM hybridization signal is dramatically reduced to background levels at the earlier time points examined $(9,14 \mathrm{~d})$ in all but a few 

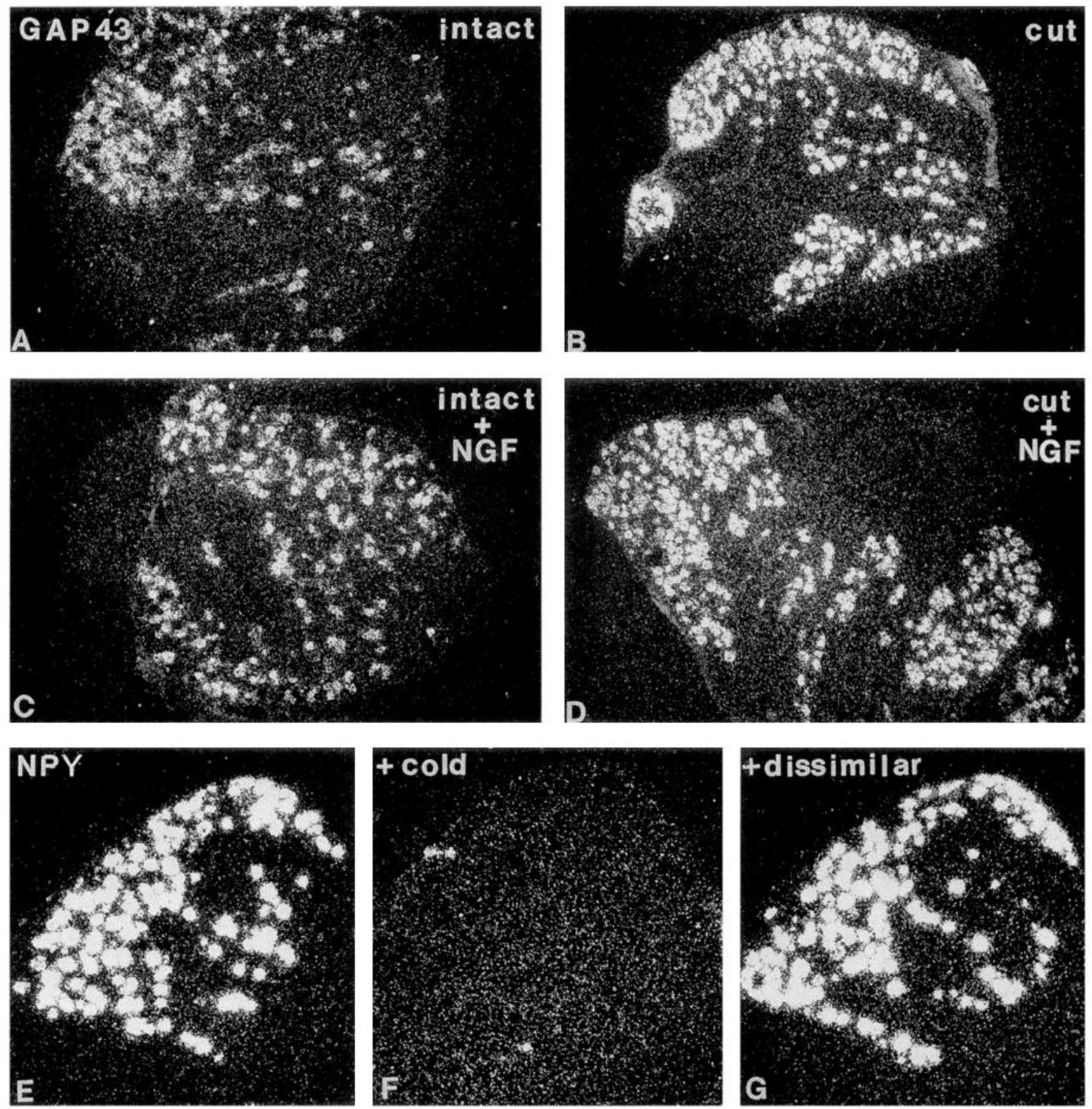

Figure 8. Dark-field photomicrographs of $\mathrm{L}_{5}$ DRG processed for in situ hybridization with probes to detect GAP43 $(A-D)$ or NPY $(E-G)$ mRNA. $A-D$ (Transection control), DRG are associated with intact sciatic nerves $(A, C)$ or sciatic nerves cut 2 weeks previously $(B, D)$ with $(C, D)$ or without $(A, B)$ infusion of NGF for 1 week following the 2 week injury period. Note the marked upregulation in expression of GAP43 in virtually all neurons in response to the injury. $E-G$ (Hybridization controls), $10 \mu \mathrm{m}$ serial sections of a $14 \mathrm{~d}$ injured DRG were hybridized with labeled NPY probe $(E)$ plus either a $400 \times$ excess of cold unlabeled NPY probe $(F)$ or a $400 \times$ excess of a dissimilar probe of similar G-C content $(G)$. Note that addition of cold NPY probe abolishes the hybridization signal, while addition of a dissimilar cold probe did not influence the pattern of hybridization. Magnification: $A-D, 35 \times ; E-G, 42 \times$.

neurons (which represent less than $1 \%$ regardless of the type of lesion). However, at later time points SOM is once again robustly expressed in approximately $7 \%$ of the neurons which had undergone the crush injury $(29,91 \mathrm{~d}$ postlesion; V.M.K. Verge, unpublished data) and presumably regenerated.

Other signals correlated with peptide plasticity in injured neurons

The immediate early gene and transcription factor, c-jun, is expressed in sensory neurons in response to injury (Jenkins and Hunt, 1991; Leah et al., 1991; Herdegen et al., 1992). Recently, Gold and colleagues (Gold et al., 1993) have shown that the loss of target derived NGF may be responsible for induction of c-jun in some neurons as its expression is induced with anti-NGF treatment and reduced in injured neurons exposed to exogenous NGF. It has also been proposed that c-jun may serve to transcriptionally regulate galanin expression due to the concomitant posttraumatic elevation of the two molecules in the same neurons (Herdegen et al., 1993). The ability of NGF to downregulate c-jun expression may be linked to the role of NGF as a reverser of injury-associated changes in peptide expression. However, the absence of retrograde supply of peripherally derived neurotrophins following axonal disruption is not the only alteration in trophic support that a neuron undergoes. There is evidence emerging supporting the role of trophic molecules whose expression is enhanced in DRG after injury as positive 
regulators of some of the injury-induced changes in peptide expression. Leukemia inhibitory factor (LIF) expression is upregulated in non-neuronal cells of both sympathetic and dorsal root ganglia either in vivo, in organ explant cultures, or dissociated non-neuronal cultures (Banner and Patterson, 1993; Sun et al., in press). In cultured adult sympathetic and neonate DRG neurons LIF can upregulate VIP expression, while antibodies to LIF partially blocked the induction in the sympathetic explants (Nawa et al., 1990; Sun et al., in press). In addition, LIF-deficient mice have compromised induction of neuropeptide expression in axotomized sympathetic neurons (Rao et al.,1993).

As NGF acts on only $\sim 40 \%$ of adult sensory neurons, other members of the NGF family of neurotrophins (NTs), namely BDNF (Barde et al., 1982; Leibrock et al., 1989), NT-3 (Ernfors et al., 1990a; Hohn et al., 1990; Kaisho et al., 1990; Maisonpierre et al., 1990; Rosenthal et al., 1990), and NT-4/5 (Berkemeir et al., 1991; Hallböök et al., 1991; Ip et al., 1992) may influence neuropeptide synthesis in those neurons lacking NGF receptors. The belief that these NTs are biologically important for sensory neurons arises from in vitro evidence showing that they promote survival and neurite outgrowth of subsets of DRG neurons and nodose sensory neurons (Lindsay et al., 1985; Leibrock et al., 1989; Hohn et al., 1990; Maisonpierre et al., 1990; Hallbook et al., 1991). The recent generation of mice with null mutations in the genes encoding BDNF or the neurotrophin receptors support this belief as the mice all displayed sensory deficits (Lee et al., 1992; Klein et al., 1993; Ernfors et al., 1994; Klein et al., 1994; Smeyne et al., 1994). Furthermore, exogenous BDNF and NT-3 are retiogradely transported to what may be overlapping as well as distinct subsets of adult DRG neurons (DiStefano et al., 1992) which corresponds to a similar neuronal distribution of the mRNA encoding their signal transducing receptor components (Verge et al., 1993c).

In conclusion, the ability of NGF to regulate peptide expression differentially in injured, mature sensory neurons supports the hypothesis that it is responsible for the reversal of injuryassociated cell body responses, perhaps as regenerating axons once again come in contact with an abundant source of neurotrophins in the Wallerian degenerating distal stump (Richardson and Ebendal, 1982; Heumann et al., 1987; Meyer et al., 1992; Funakoshi et al., 1993).

\section{References}

Aldskogius H, Arvidsson J, Grant G (1985) The reaction of primary sensory neurons to peripheral nerve injury with particular emphasis on transganglionic changes. Brain Res Rev 10:27-46.

Aldskogius H, Arvidsson J, Grant G (1992) Axotomy-induced changes in primary sensory neurons, In: Sensory neurons - diversity, development and plasticity (Scott SA, ed), pp 363-383. New York: Oxford UP.

Amara SG, Arriza JL, Leff SE, Swanson LW, Evans RM, Rosenfeld MG (1985) Neuropeptide homologous to calcitonin gene-related peptide. Science 229:1094-1097.

Arvidsson J, Ygge J, Grant G (1986) Cell loss in lumbar dorsal root ganglia and transganglionic degeneration after sciatic nerve resection in the rat. Brain Res 162:1-12.

Banner LR, Patterson PH (1993) Tissue distribution, developmental expression and response to injury of rat CDF/LIF and its receptor. Soc Neurosci $\Lambda$ bstr 19:6.

Barde Y-A, Edgar D, Thoenen H (1982) Purification of a new neurotrophic factor from brain. EMBO J 1:549-553.

Barron KD (1983) Comparative observations on the cytologic reactions of central and peripheral nerve cells to axotomy. In: Spinal cord reconstruction (Kao CC, Bunge RP, Reier PJ, eds), pp 7-40. New York: Raven

Berkemeier LR, Winslow JW, Kaplan DR, Nikolics K, Goeddel DV,
Rosenthal A (1991) Neurotrophin-5: a novel neurotrophic factor that activates trk and trkB. Neuron 7:857-866.

Buchan AMJ, Sikora LKJ, Lovy JG, McIntosh CHS, Dyck I, Brown JC (1985)An immunohistochemical investigation with monoclonal antibodies to somatostatin. Histochemistry 83:175-180.

Carroll SL, Silos-Santiago I, Frese SE, Ruit KG, Milbrandt J, Snide WD (1992) Dorsal root ganglion neurons expressing trk are selectively sensitive to NGF deprivation in utero. Neuron 9:779-788.

Coons AH (1958) Fluorescent antibody methods. In: General cytochemical methods (Danielli JF, ed), pp 399-422. New York: Academic.

Cragg BG (1970) What is the signal for chromatolysis? Brain Res 23: $1-21$.

Csillik B, Scwab M, Theonen H (1985) Transganglionic regulation of the central terminals of dorsal root ganglion cells by nerve growth factor (NGF). Brain Res 331:11-15.

Dagerlind A, Friberg K, Bean AJ, Hökfelt T (1992) Sensitive mRNA detection using unfixed tissue: combined radioactive and non-radioactive in situ hybridization histochemistry. Histochemistry 98:39-49.

Davis BM, Lewin GR, Mendell LM, Jones ME, Albers KM (1993) Altered expression of nerve growth factor in the skin of transgenic mice leads to changes in response to mechanical stimuli. Neuroscience 56:789-792

Deschenes RJ, Lorenz LJ, Haun RS, Roos BA, Collier KJ, Dixon JE (1984) Cloning and sequence analysis of cDNA encoding rat PPT. Proc Natl Acad Sci USA 81:726-730.

DiStefano PS, Friedman B, Radziejewski C, Alexander C, Boland P, Schick CM, Lindsay RM, Wiegand SJ (1992) The neurotrophins BDNF, NT-3 and NGF display distinct patterns of retrograde transport in peripheral and central neurons. Neuron 8:983-993.

Donaldson LF, Harmar AJ, McQueen DS, Seckl JR (1992) Increased expression of preprotachykinin, calcitonin gene-related peptide, but not vasoactive intestinal peptide messenger RNA in dorsal root ganglia during the development of adjuvant monoarthritis in the rat. Mol Brain Res 16:143-149.

Donnerer J, Schuligoi R, Stein C (1992) Increased content and transport of substance $\mathrm{P}$ and calcitonin gene-related peptide in sensory nerves innervating inflamed tissue: evidence for a regulatory function of nerve growth factor in vivo. Neuroscience 49:693-698.

Ernfors P, Ibanez CF, Ebendal T, Olson L, Persson H (1990) Molecular cloning and neurotrophic activities of a protein with structural similarities to nerve growth factor: developmental and topographical expression on the brain. Proc Natl Acad Sci USA 87:5454-5458.

Ernfors P, Kuo-Fen L, Jaenisch R (1994) Mice lacking brain-derived neurotrophic factor develop with sensory deficits. Nature 368:147150.

Fitzgerald M, Wall PD, Goedert M, Emson C (1985) Nerve growth factor counteracts the neurophysiological and neurochemical effects of chronic sciatic nerve section. Brain Res 332:131-14l.

Funakoshi H, Frisén J, Barbany G, Timmusk T, Zachrisson O, Verge VMK, Persson H (1993) Differential expression for neurotrophins and their receptors following axotomy of the sciatic nerve. J Cell Biol 123:455-465

Gamse R, Saria A (1986) Nociceptive behavior after intrathecal injection of substance $P$, Neurokinin A and calcitonin gene-related peptide in mice. Neurosci Lett 70:143-147.

Goedert M, Stocckel K, Otten U (1981) Biological importance of the retrograde axonal transport of nerve growth factor in sensory neurons. Neuroscience 78:5895-5898.

Goedert M, Fine A, Hunt SP, Ullrich A (1986) Nerve growth factor mRNA in peripheral and central rat tissues and in human central nervous system: lesion effects in the rat brain and levels in Alzheimer's disease. Brain Res 387:85-92.

Gillardon F, Morano I, Zimmermann M (1991) Ultraviolet irradiation of the skin attenuates calcitonin gene-related peptide mRNA expression in rat dorsal root ganglion cells. Neurosci Lett 124:144-147.

Gold BG, Storm-Dickerson T, Austin DR (1993) Regulation of the transcription factor c-JUN by nerve growth factor in adult sensory neurons. Neurosci Lett 154:129-133.

Goodman RH, Aron DC, Ross BA (1989) Rat pre-prosomatostatin. J Biol Chem 258:5570-5573.

Gorin PD, Johnson EM Jr (1980) Effects of long term nerve growth factor deprivation on the nervous system of the adult rat: an experimental autoimmune approach. Brain Res 198:27-42.

Grafstein B (1983) Chromatolysis reconsidered: a new view of the 
reaction of the nerve cell body to axon injury. In: Nerve, organ and tissue regeneration: research perspectives (Seil FJ, ed), pp 37-50. New York: Academic.

Grafstein B, McQuarrie IG (1978) The role of the nerve cell body in axonal regeneration. In: Neuronal plasticity (Cotman $\mathrm{CW}$, ed), pp 155-195. New York: Raven.

Greenberg SG, Lasek RJ (1988) Neurofilament protein synthesis in DRG neurons decreases more after peripheral axotomy than central axotomy. J Neurosci 8:1739-1746.

Hallböök F, Ibáñez CF, Persson II (1991) Evolutionary studies of the nerve growth factor family reveal a novel member abundantly expressed in Xenopus ovary. Neuron 6:845-858.

Henry JL (1976) Effects of substance P on functionally identified units in cat spinal cord. Brain Res 114:439-451.

Herdegen T, Fiallos-Estrada CE, Bravo R, Zimmermann M (1993) Colocalisation and covariation of $\mathcal{C}-J U N$ transcription factor with galanin in primary afferent neurons and with CGRP in spinal motoneurons following transection of rat sciatic nerve. Mol Brain Res 17:147-154.

Heumann R, Korsching S, Bandtlow C, Thoenen H (1987) Changes in nerve growth factor synthesis in nonneuronal cells in response to sciatic nerve transection. J Cell Biol 104:1623 1631 .

Himes BT, Tessler A (1989) Death of some dorsal root ganglion neurons and plasticity of others following sciatic nerve section in adult and neonatal rats. J Comp Neurol 284:215-230.

Hoffman PN, Cleveland DW (1988) Neurofilament and tubulin gene expression recapitulates the developmental program during regeneration: induction of a specific $\beta$-tubulin isotype. Proc Natl Acad Sci USA 85:4530-4533.

Hohn A, Leibrock J, Bailey K, Barde YA (1990) Identification and characterization of a novel member of the nerve growth factor/brainderived neurotrophic factor family. Nature 344:339-341.

Hökfelt, T, Wiesenfeld-Hallin Z, Villar M, Melander T (1987) Increase of galanin-like immunoreactivity in rat dorsal root ganglion cells after peripheral axotomy. Neurosci Lett 83:217-220.

Inaishi Y, Kashihara Y, Sakaguchi M, Nawa II, Kuno M (1992) Cooperative regulation of calcitonin gene-related peptide levels in rat sensory neurons via their central and peripheral processes. J Neurosci $12: 518-524$.

Ip NY, Ibáñez CF, Nye SH, McLain J, Jopnes PF, Gies DR, Belluscio L, Le Beau MM, Espinosa R III, Squinto SP, Persson H, Yancopoulus GD (1992)Mammalian neurotrophin-4: structure, chromosomal localization, tissue distribution and receptor specificity. Proc Natl Acad Sci UISA 89:3060-3064.

Jenkins R, Hunt SP (1991) Long term increase in the levels of c-jun mRNA and Jun protein-like immunoreactivity in motor and sensory neurons following axonal damage. Neurosci Lett 129:107-110.

Jessell T, Tsunoo A, Kanasawa I, Otsuka M (1979) Substance P: depletion in the dorsal horn of rat spinal cord after section of the peripheral processes of primary sensory neurons. Brain Res 168:247259.

Kaisho Y, Yoshimura K, Nakahama K (1990) Cloning and expression of a cDNA encoding a novel human neurotrophic factor. FEBS Lett 266:187-191.

Karns LR, NG SG, Freeman JA, Fishman MC (1987) Cloning of cDNA for GAP43, a neuronal growth-related protein. Science 236: $597-600$.

Kashiba H, Senba E, Kawai Y, Ueda Y, Tohyama M (1992) Axonal blockade induces the expression of vasoactive intestinal polypeptide and galanin in rat dorsal root ganglion neurons. Brain Res 577:19_ 28 .

Kessler JA, Adler JE, Bohn MC, Black IR (1981) Substance P in principal sympathetic neurons: regulation by impulse activity. Nature 214:335-336

Klein R, Smeyne RL, Wurst W, Long LK, Auerbach BA, Joyner AL, Barbacid M (1993) Targeted disruption of the trkB neurotrophin receptor gene results in nervous system lesions and neonatal death. Cell 75:113-122.

Klein R, Silos-Santiago I, Smeyne RJ, Lira SA, Brambilla R, Bryant S, Zhang L, Snyder WD, Barbacid M (1994) Disruption of the neurotrophin-3 receptor gene trkC eliminates Ia muscle afferents and results in abnormal movements. Nature 368:249 251.

Knyihar-Csillik E, Kreutzberg GW, Raivich G, Csillik B (1991) Vasoactive intestinal polypeptide in dorsal root terminals of the rat spinal cord is regulated by the axoplasmic transport in the peripheral nerve. Neurosci Lett 131:83-87.
Korsching S, Thoenen H (1983) Nerve growth factor in sympathetic ganglia and corresponding target organs of the rat: correlation with density of sympathetic innervation. Proc Natl Acad Sci USA 80: 3513-3516.

Krause JE, Chirgwin JM, Carter MS, XU ZS, Hershey D (1987) Three rat PPT mRNAs encode the neuropeptides SP and NKA. Proc Natl Acad Sci USA 84:881-885.

Kuraishi Y, Nanayama T, Ohno H, Fujic N, Otaka A, Yajima H, Satoh M (1989) Calcitonin gene-related peptide increases in the dorsal root ganglia of adjuvant arthritic rat. Peptide 10:447-452.

Larhammar D, Ericsson A, Persson H (1987) Structure and expression of the rat neuropeptide Y gene. Proc Natl Acad Sci USA 84:20682072.

Leah JD, Herdegen T, Bravo R (1991) Selective expression of Jun proteins following axotomy and axonal transport block in peripheral nerves in the rat: evidence for a role in the regeneration process. Brain Res 566: 198-207.

Lee KF, Li E, Huber LJ, Landis SC, Sharpe AH, Chan MV, Jaenisch R (1992) Targeted mutation of the gene encoding the low affinity NGF receptor p75 leads to deficits in the peripheral sensory nervous system. Cell 69:737-749.

Leibrock J, Lottspeich F, Hohn A, Hofer M, Hengerer B, Masiakowski P, Thoenen H, Barde YA (1989) Molecular cloning and expression of brain-derived neurotrophic factor. Nature 341:149-152.

Lembeck F, Donnerer J, Colpart FC (1981) Increase of substance P in primary afferents during chronic pain. Neuropeptides 1:175-180.

Levi-Montalcini R, Angeletti PU (1968) Nerve growth factor. Physiol Rev 48:534-569.

Lewin GR, Ritter AM, Mendell LM (1992) On the role of nerve growth factor in the development of myelinated nociceptors. J Neurosci 12:1896-1905.

Lewin GR, Ritter, AM, Mendell LM (1993) Nerve growth factor-induced hyperalgesia in the neonatal and adult rat. J Neurosci 13:21362148.

Lieberman AR (1971) The axon reaction: a review of the principal features of perikaryal responses to axon injury. Int Rev Neurobiol $14: 49-124$.

Lieberman AR (1974) Some factors affecting retrograde neuronal responses to axonal lesions. In: Essays on the nervous system (Bellairs R, Gray EG, eds), pp 71-105. Oxford: Clarendon.

Lindsay RM (1988) Nerve growth factors (NGF, BDNF) enhance axonal regeneration but are not required for survival of adult sensory neurons. J Neurosci 8:2394-2405.

Lindsay RM, Harmar AJ (1988) Nerve growth factor regulates expression of neuropeptide genes in adult sensory neurons. Nature 337: $362-364$.

Lindsay RM, Thoenen H, Barde YA (1985) Placode and neural crestderived sensory neurons are responsive at an early age to brain-derived neurotrophic factor (BDNF). Dev Biol 112:319-328.

Lindsay RM, Lockett C, Sternberg J, Winter J (1989) Neuropeptide expression in cultures of adult sensory neurons: modulation of substance $\mathrm{P}$ and calcitonin gene-related peptide levels by nerve growth factor. Neuroscience 33:53-65.

Longo FM, Woo JE, Mobley WC (1989) Purification of nerve growth factor. In: Nerve growth factors (Rush RA, ed), pp 3-30. Chichester: Wiley.

Maisonpierre PC, Bellucio L, Squinto S, Ip NY, Furth ME, Lindsay RM, Yancopoulus GD (1990) Neurotrophin-3: a neurotrophic factor related to NGF and BDNF. Science 247:1446-1451.

Mao J, Coghill RC, Kellstein DE, Frenk II, Mayer DJ (1992) Calcitonin gene-related peptide enhances substance P-induced behaviors via metabolic inhibition: in vivo evidence for a new mechanism of neuromodulation. Brain Res 574:157-163.

Meakin SO, Suter U, Drinkwater CC, Welcher AA, Shooter, EM (1992) The rat trk protooncogene exhibits properties characteristic of the slow NGF receptor. Proc Natl Acad Sci USA 89:2374-2378.

Merlio JP, Ernfors P, Jaber M, Persson H (1992) Molecular cloning of the rat trkC and identification of cells expressing mRNAs for members of the trk family in the rat central nervous system, Neuroscience 51:513-532.

Meyer M, Matsuoka I, Wetmore C, Olson L, Thoenen H (1992) Enhanced synthesis of brain-derived neurotrophic factor in the lesioned peripheral nerve: different mechanisms are responsible for the regulation of BDNF and NGF mRNA. J Cell Biol 119:45-54.

Moskowitz PF, Smith R, Pickett J, Frankfurter A, Oblinger MM (1993) 
Expression of the class III b-tubulin gene during axonal regeneration of rat dorsal root ganglion neurons. J Neurosci 34:129-134.

Mulderry PK, Lindsay RM (1990) Rat dorsal root ganglion neurons in culture express vasoactive intestinal polypeptide (VIP) independently of nerve growth factor. Neurosci Lett 108:314-320.

Nawa H, Yamamori T, Le T, Patterson PH (1990) Generation of neuronal diversity: analogies and homologies with hematopoiesis. Cold Springs Harbor Symp Quant Biol 50:247-253.

Nielsch U, Keen P (1989) Reciprocal regulation of tachykinin- and vasuactive intestinal peptide-gene expression in rat sensory neurons following cut and crush injury. Brain Res 481:25-30.

Nishizawa M, Hayakawa Y, Yanaihara N, Okamoto H (1985) Nucleotide sequence divergence and functional restraint in VIP precursor mRNA evolution between human and rat. FEBS Lett 183:55-59.

Noguchi K, Senba E, Morita Y, Sato M, Tohyama M (1989) PreproVIP preprotachykinin mRNAs in the rat dorsal root ganglion cells following peripheral axotomy. Mol Brain Res 6:327-330.

Noguchi K, Senba E, Morita Y, Sato M, Tohyama M (1990) a-CGRP and $\beta$-CGRP mRNAs are differentially regulated in the rat spinal cord and dorsal root ganglion. Mol Brain Res 7:299-304.

Noguchi K, De Léon M, Nahin RL, Ruda MA (1993) Quantification of axotomy-induced alteration of neuropeptide mRNAs with special reference to neuropeptide Y mRNA and the effects of neonatal capsaicin treatment. J Neurosci Res 35:54-66.

Pease PC (1962) Buffered formaldehyde as a killing agent and primary fixative for electron microscopy. Anat Rec 142:342.

Platt JL, Micheal AF (1983) Retardation of fading and enhancement of intensity of immunofluorescence by $p$-phenylenediamine. J Histochem Cytochem 31:840-842.

Raivich G, Hellweg R, Kreutzberg GW (1991) NGF receptor-mediated reduction in axonal NGF uptake and retrograde transport following sciatic nerve injury and during regeneration. Neuron 7:151-164.

Rao MS, Sun Y, Escary JL, Perreau J, Tresser S, Patterson PH, Zigmond RE, Brulet $\mathbf{P}$, Landis SC (1993) Leukemia inhibitory factor mediates an injury response but not a target-directed developmental transmitter switch in sympathetic neurons. Neuron 11:1175-1185.

Richardson PM, Ebendal T (1982) Nerve growth activities in rat peripheral nerve. Brain Res 246:57-64.

Richardson PM, Riopelle RJ (1984) Uptake of nerve growth factor along peripheral and spinal axons of primary sensory neurons. J Neurosci 4:1683-1689.

Richardson PM, Verge Issa, VMK, Riopelle, RJ (1986) Distribution of neuronal receptors for nerve growth factor in the rat. J Neurosci 6:2312-2321.

Ritter AM, Mendell LM (1992) The somal membrane properties of physiologically identified sensory neurons in the rat: effects of nerve growth factor. J Neurophysiol 68:2033-2041.

Ritter AM, Lewin GR, Kremer NE, Mendell LM (1991) Requirement for nerve growth factor in the development of myelinated nociceptors in vivo. Nature 350:500-502.

Rosenthal A, Goeddel DV, Nguyen T, Lewis M, Shih A, Laramee GR, Nikolics K, Winslow JW (1990) Primary structure and biological activity of a novel human neurotrophic factor. Neuron. 4:767-773.

Ruit KG, Elliott JL, Osbourne PA, Yan Q, Snider WD (1992) Selective dependance of mammalian dorsal root ganglion neurons on nerve growth factor during embryonic development. Neuron 8:573-587.

Salt TE, Hill RG (1983) Neurotransmitter candidates of somatosensory primary afferent fibres. Neuroscience 10:1083-1103.

Schwartz JP, Pearson J, Johnson EM (1982) Effect of exposure to antiNGF on sensory neurons of adult rats and guinea pigs. Brain Res 244:378-381.

Shehab SAS, Atkinson ME (1986a) Vasoactive intestinal polypeptide increases in areas of the dorsal horn of the spinal cord from which other neuropeptides are depleted following peripheral axotomy. Exp Brain Res 62:422-430.

Shehab SAS, Atkinson ME (1986b) Vasoactive intestinal polypeptide (VIP) increases in the spinal cord after peripheral axotomy of the sciatic nerve originate from primary afferent neurons. Brain Res 372 : $37-44$.

Shelton DL, Reichardt LF (1984) Expression of the $\beta$-NGF gene correlates with the density of sympathetic innervation in effector organs. Proc Natl Acad Sci USA 81:7951-7955.

Skene JHP, Willard M (1981) Axonally transported proteins associated with axon growth in rabbit central and peripheral nervous system. J Cell Biol 89:96-103.
Smeyne RJ, Klein R, Schnapp A, Long LK, Bryant S, Lewin A, Lira SA, Barbacid M (1994) Severe sensory and sympathetic neuropathies in mice carrying a disrupted trk/NGF receptor gene. Nature 368 : 246-249.

Stoekel K, Paravincini U, Thoenen H (1974) Specificity of the retrograde axonal transport of nerve growth factor. Brain Res 76:413-421.

Sun Y, Rao MS, Zigmond RE, Landis SC (in press) Regulation of vasoactive intestinal peptide expression in sympathetic neurons in culture and after axotomy: the role of cholinergic differentiation factor/leukemia inhibitory factor. J Neurobiol, in press.

Taiwo YO, Levine JD, Burch RM, Woo JE, Mobley WC (1991) Hyperalgesia induced in the rat by the amino-terminal octapeptide of nerve growth factor. Proc Natl Acad Sci USA 88:5144-5148.

Tessler A, Himes BT, Krieger NR, Murray M, Goldberger ME (1985) Sciatic nerve transection produces death of dorsal root ganglion cells and reversible loss of substance P in spinal cord. Brain Res 332:209218

Tetzlaff W, Zwiers H, Lederis K, Cassar L, Bisby MA (1989) The axonal transport and localization of b-50/GAP43-like immunoreactivity in regenerating sciatic and facial nerves of the rat. $\mathbf{J}$ Neurosci 9:1303-1313.

Van der Zee CEEM, Nielander HB, Vos JP, Lopes da Silva S, Verhaagen J, Oestreicher AB, Schrama LH, Schotman P, Gispen WH (1989) Expression of growth associated protein B50 (GAP43) in dorsal root ganglia and sciatic nerve during regenerative sprouting. J Neurosci 9:3505-3512.

Verge VMK, Riopelle RJ, Richardson PM (1989a) Nerve growth factor receptors on normal and injured sensory neurons. J Neurosci 9:914 922.

Verge VMK, Richardson PM, Benoit R, Riopelle R (1989b) Histochemical characterization of sensory neurons with high-affinity receptors for nerve growth factor. J Neurocytol 18:583-591.

Verge VMK, Tetzlaff W, Richardson PM, Bisby MA (1990a) Correlation between GAP43 and nerve growth factor receptors in rat sensory neurons. J Neurusci 10:926-934.

Verge VMK, Tetzlaff W, Bisby M, Richardson PM (1990b) Influence of nerve growth factor on neurofilament gene expression immature primary sensory neurons. J Neurosci 10:2018-2025.

Verge VMK, Merlio JP, Grondin J, Ernfors P, Persson H, Riopelle RJ, Hökfelt T, Richardson PM (1992a) Colocalization of NGF binding sites, trk mRNA, and low-affinity NGF receptor mRNA in primary sensory neurons: responses to injury and infusion of NGF. J Neurosci $12: 4011-4022$

Verge VMK, Richardson PM, Wiesenfeld-Hallin Z, Hökfelt T (1992b) Differential influence of nerve growth factor on neuropeptide expression in vivo-a novel role in peptide suppression. Soc Neurosci Abstr 18:1098.

Verge VMK, Xu X-J, Langel U, Hökfelt T, Wiesenfeld-Hallin Z, Bartfai T (1993a) Evidence for endogenous inhibition of autotomy by galanin in the rat after sciatic nerve section: demonstrated by chronic infusion of a high-affinity galanin receptor antagonist. Neurosci Lett 149:193-197.

Verge VMK, Wiesenfeld-Hallin Z, Hökfelt T (1993b) Cholecystokinin in mammalian primary sensory neurons and spinal cord: in situ hybridization studies on rat and monkey spinal ganglia. Eur J Neurosci $5: 240-250$

Verge VMK, Wetmore C, Hökfelt T (1993c) Colocalization studies of trk, trkB, and trkC receptor mRNA expression in primary sensory neurons and responses to injury. Soc Neurosci Abstr 19:1476.

Villar MJ, Cortes R, Theodorsson E, Wiesenfeld-Hallin Z, Schlalling M, Fahrenkrug J, Emson PC, Hökfelt T (1989) Neuropeptide expression in rat dorsal root ganglion cells and spinal cord after peripheral nerve injury with special reference to galanin. Neuroscience 33:587-604.

Vrontakis ME, Peden LM, Duckworth ML, Friesen HG (1987) Isolation and characterization of a complimentary DNA (galanin) clone from estrogen-induced pituitary tumor messenger RNA. J Biol Chem 262:16755-16758

Wakisaka S, Kajander KC, Bennett GJ (1991) Increased neuropeptide (NPY)-like immunoreactivity in rat sensory neurons following peripheral axotomy. Neurosci Lett 124:200-203.

Weskamp G, Otten U (1987) An enzyme-linked immunoassay for nerve growth factor (NGF): a tool for studying regulatory mechanisms involved in NGF production in brain and peripheral tissues. $J$ Neurochem 48:1779-1786.

Wiesenfeld-Hallin Z (1986) Somatostatin and calcitonin gene-related 
peptide synergistically modulate spinal scnsory and reflex mechanisms in the rat: behavioral and electrophysiological studies. Neurosci Lett 67:319-323.

Wiesenfeld-Hallin Z, Hökfelt T, Lundberg JM, Forsmann WG, Reinecke M, Tschopp FA, Fischer JA (1984) Immunoreactive calcitonin generelated peptide and substance $P$ coexist in sensory neurons to the spinal cord and interact in spinal behavioral responses of the rat. Neurosci Lett 52:199-204.

Wiesenfeld-Hallin Z, Villar MJ, Hökfelt T (1989a) The effect of intrathecal galanin and $C$-fiber stimulation on the flexor reflex in he rat. Brain Res 486:205-213.

Wiesenfeld-Hallin Z, Xu X-J, Villar MJ, Hökfelt T (1989b) The effect of intrathecal galanin on the flexor reflex in rat: increased depression after sciatic nerve section. Neurosci Lett 105:149-154.

Wiesenfeld-Hallin Z, Xu X-I, Hughes I, Horwell DC. Hökfelt T (1990) PD134308, a selective antagonist of cholecystokinin type-B receptor, enhances the analgesic effect of morphine and synergistically interacts with intrathecal galanin to depress spinal nociceptive reflexes. Proc Natl Acad Sci USA 87:7105-7109.

Wiesenfeld-Hallin Z, Xu X-J, Langel U, Bedecs K, Hökfelt T, Bartfai $T$ (1992) Galanin-mediated control of pain: enhanced role after nerve injury. Proc Natl Acad Sci USA 89:3334-3337.
Wong J, Oblinger MM (1991) NGF rescues SP expression but not neurofilament or tubulin gene expression in axotomized sensory neurons. J Neurosci 11:543-552.

Woolf CJ, Wiesenfeld-Hallin $Z$ (1986) Substance P and calcitonin gene-related peptide synergistically modulate the gain of the nociceptive flexor withdrawal reflex in the rat. Neurosci Lett 66:319-323.

Xu X-J, Puke MJC, Verge VMK, Wiesenfeld-Hallin Z, Hughes J, Hökfelt T (1993) Up-regulation of cholecystokinin in primary sensory neurons is associated with morphine insensitivity in experimental neuropathic pain in the rat. Neurosci Lett 152:129-132.

Zamboni I, DeMartino C (1967) Buffered picric acid formaldehyde. A new rapid fixative for electron microscopy. J Cell Biol 35:148.

Zhang X, Meister B, Elde R, Verge VMK, Hökfelt T (1993) Large calibre primary afferent neurons projecting to the gracile nucleus express neuropeptide $Y$ atter sciatic nerve lesions: an immunohistochemical and in situ hybridization study in rats. Eur J Neurosci 5:1510-1519.

Zigmond RE, Hyatt-Sachs H, Baldwin C, Qu XM, Sun Y, McKeon TW, Schreiber RC, Vaidyanathan U (1992) Phenotypic plasticity in adult sympathetic neurons: changes in neuropeptide expression in organ culture. Proc Natl Acad Sci USA 89:1507-1511. 